\title{
The potential of urban agriculture for sustainability of cities in Poland
}

\author{
Rafal Jasionkowski, Anna Lewandowska-Czarnecka*
}

Nicolaus Copernicus University, Faculty of Biology and Environment Protection, Chair of Geobotany and Landscape Planning, Lwowska 1, 87-100 Toruń, Poland, *e-mail: lewandow@umk.pl

\begin{abstract}
Town planners specialising in the sustainable development and self-sufficiency of urban areas have recently encouraged a solution called urban agriculture, which means that urban inhabitants can produce food for themselves. The main objective of this paper is to present the possibilities of food production in a city especially in the context of sustainable development. The idea of crop cultivation as well as its implementation in the form of e.g. greenhouses, allotments or even gardens dates back centuries. Nevertheless, with time and technology development, new forms of ecological farms have been designed. Urban agriculture can play an important role in the sustainable development of cities.
\end{abstract}

Key words: sustainable development, urban agriculture, green roof, city farm, window farm, window garden, vertical garden.

\section{Introduction}

The future of mankind is connected with big urban agglomerations. In 1950 , only $30 \%$ of the population worldwide dwelled in urban areas, whereas at present over $50 \%$ of the world's population lives in towns and cities. It thus appears that the world's population growth rate as well as the level of urban development and degradation of the environment is particularly high. The three processes mentioned above are closely related and make the future look very pessimistic. Basically, a city can prosper owing to its organization, which should match the sustainable development principles and minimize harmful impact on the environment, yet ensure the social and economic development with respect for the cultural heritage (Walkow, 2015). Ecology has recently become a fast-growing branch of science, entering into our everyday life, starting from food processing and ending with industrial technologies and architecture. The development of technology along with the ability to use it properly can be advantageous to nature. Since futuristic concepts of urban farms experience today a period of great interest, innovative solutions contributing to the restoration of harmony in the urban environment, through the implementation of environmental projects, have become the object of my interest and the subject of the presented discussions.

The purpose of this article is to review the possibilities of food production in a city, which has been observed in developed countries, for example in the UK. The article explores various forms of urban agriculture, especially in the context of sustainable development, as well as it presents the current situation of urban food production based on the example of Poland.

\section{Sustainable development}

The issue of efficient management of natural resources is associated with the adaptation of social and economic development to the environment. The most important in this case is the principle of sustainable development. It aims at integrating the management of the environment with 
its protection against adverse effects of human activities (Dobrzańska, 2007). The United Nations Conference on Environment and Development, which took place in 1992 in Rio de Janeiro and resulted in signing the Rio Declaration on Environment and Development, was a milestone in the political approach to the sustainable development (Poskrobko, 2009). And what exactly is sustainable development?

It is a kind of process of social, economic and environmental changes, which provides a long-term balance between costs and benefits. To succeed, such a development should be constantly stimulated and any adverse effects should be avoided (Ustawa..., 2001).

\section{Urban agriculture}

In recent years, urban cultivation of crops has become increasingly popular. Urban agriculture is beneficial on many levels: it enables people to produce fresh vegetables, fruit and herbs without using artificial fertilizers or pesticides. Moreover, urban fields affect the growth of biological diversity, improve the microclimate, produce oxygen and, which is paramount, absorb the carbon dioxide. Urban agricultural areas are dedicated to cultivation, processing and distribution of food in urban areas. Urban farming means also breeding animals, urban apiculture, aquaculture and gardening (Bailkey \& Nasr 2001).

Urban agriculture can also reflect various levels of social and economic development, for instance, urban food processing was a necessity during the war period. In recent years, however, the society seeks to create a new model of life that would be more environmentally friendly and sustainable. Nowadays, urban farming is claimed to be a promising branch of human activity, which may contribute to helping the developing countries improve their social and economic level (Wilkin, 2010).

\section{Forms of urban agriculture}

Analysis of contemporary urban structures has laid the foundations for the development of various ideas of urban crop cultivation. My work presents the increasingly popular innovative forms of urban management, which support the cultivation of crops, i.e. green roofs, city farms, window farms (or window gardens) and vertical gardens.

\section{1. Green roofs}

A green roof means an open area of roof covered with plants. This is one of the world's popular ways of eco-compensation, i.e. investing in a given area in such a way that it increases its environmental value. It is important that green structures can be implemented not only in the new investments, but also in the those that already exist. The more popular the green roofs become, the more diversity in both the plant cover and its purpose can be observed. A widespread type of green roofs is dedicated to the restoration of a biologically active surface in towns and is usually not available for use. This is an environmentally useful space which provides a habitat for birds and other animals (Sznajda-Birnfeld et al., 2012).

Another type of green roofs are intensive green roofs, often referred to as roof gardens as this name reflects their nature. The roofs are usually flat and resemble standard gardens or farms (Rabiński, 2011). It is important to build them properly so they can support an additional weight (up to $1500 \mathrm{~kg}$ per $\mathrm{m}^{2}$ ), so as to be able to cultivate there a wide range of perennials, bushes and trees and to build additional elements, such as ponds, garden sculptures or garden houses. Introduction of the elements listed above will need to ensure a proper thickness of a vegetation layer, which can be up to $125 \mathrm{~cm}$. Food produced on the roof of the workplace or dwelling houses will be fresher, healthier and cheaper because of, inter alia, the lack of transportation cost (Kania et al., 2013).

\subsection{Vertical garden}

Currently, the most popular type of unconventional urban farms are vertical gardens, which support growing of not only perennials and creepers but also bushes on the facades of buildings. They can be created on both outer and inner walls, in both public space and private houses. The main advantage of creating the green walls is the functional use of building facades, which brings benefits to ecology of urban areas as well as their inhabitants (Bribach, 2014).

Vertical gardens are vertical constructions fixed to the wall, made of a lightweight frame which is mounted on a special fabric supporting plants and preventing the use of an automatic water spraying system. The purpose of the fabric is to support the roots as well as to maintain an appropriate amount of moisture and nutritive substances. The implemented watering system distributes also a fertilizer which is necessary to nourish the plants. In case the daylight is not available, it is possible to use artificial light, which helps to locate the green wall inside or in a shady place (Kania et al., 2013).

\section{3. City farms}

City farms are environment- and agriculture-friendly projects which enable people at all age to visit a real farm located in the city centre. They promote the development of wastelands in an environmentally friendly way, while providing at the same time multiple benefits. Their activity aims at improving the lifestyle in terms of healthy nu- 
trition, environmental protection and sustainable development, since the creation of a city farm ensures increased awareness of issues such as environmental degradation, the use of renewable resources of the Earth and the reduction of pollution resulting from the wasteful use of natural resources. The main purpose of building a city farm is to persuade people to live according to nature by practical activities as well as supporting the strategy of sustainable development and eco-development of urban areas. This can be achieved through the development of environmentally friendly areas, acceleration of organic waste recycling, improvement of water management, affecting the climate and biological diversity of urban wildlife (Palej, 2010).

\subsection{Window gardens}

They are the most simple and popular forms of cultivation of vegetables, fruit and plants in a city. City farms are varied due to a wide range of technologies. The most popular one is cultivation of herbs in flowerpots situated on the windowsills. It is the best way to keep fresh herbs within easy reach so you can use them anytime and enjoy their freshness in the dishes. We can also plant fruit, vegetables and herbs on a balcony. The main advantages of window and balcony gardens are extension of the growing season and increased control over the development of plants and their availability.

\section{The impact of agriculture on sustainable development of urban areas}

The scheme presented below (Fig. 1) shows that the objective of the sustainable development principle is to ensure a long-term economic success as well as social and economic development, social stability and environmental protection.

Prevention of progressive degradation of the urban environment consists mainly in developing the effective methods of ecological compensation and investing in a special innovative form of urban green space. The concept of urban farms as a compensation for the potential green space, currently unused or occupied by a building, is becoming increasingly popular throughout the world (Gicewicz, 2005).

The main purpose of any forms of urban agriculture is to support the strategy of sustainable development and ecological development of a given city. The undeniable advantages of green roofs, farms, window gardens and living walls (made for food production) include:

- reduction of the adverse effect of urban heat islands

- restoration of green space lost during the land development

- absorption of dust and carbon dioxide
- increase in biodiversity of the urban wildlife

- acceleration of organic waste recycling

- reduction and delay in the rainwater outflow

- improvement of the microclimate and aesthetics of the landscape

- increase in public environmental awareness

- creation of new workplaces

- production of healthy food

- reduction of transportation cost of food coming from non-urban farms

- reduction of food packaging production

- improvement in lifestyle of urban areas inhabitants.

Moreover, through the creation of modern farms we contribute to the improvement in the quality of the urban environment, the use of renewable resources and the reduction of pollution as well as elimination of the wasteful use of natural resources (Denisowski, 2001).

\section{Contribution of city farming to food production and observed processes}

Urban areas produce one-fifth of the global amount of food. This applies mainly to developing countries. Currently, the production of food in cities is also growing in developed countries. What problems can be solved in these countries? It is a well-known fact that there has been an increase in the agricultural production on an industrial level (Lewandowska-Czarnecka et al., 2015). Food, and particularly its quality, is subject to criticism for health reasons. There are indications that people have begun to produce food themselves without chemical additives in small areas, such as their places of residence. On the one hand, this applies mainly to people with high incomes who can produce herbs and spice plants instead of buying them in supermarkets, which increases the prestige of their families. In addition, it also provides jobs for people who are temporarily out of work. On the other hand, the commercial production of food in cities should be based on new, rapidly developing technologies suited to small urban spaces. With such strategies, the yield of highly productive crops used in urban production is more than 40 times higher than in open areas. In general, the development of farming in cities requires support from the government. This is mainly due to the reduction in the area, especially in urban gardens which are converted into parking areas. In order to combat the decrease in the production of more useful plants on such a small scale, the United Kingdom needs to support the agriculture in the interest of towns and consider the usefulness of this operation. What actions have been taken on this issue in the UK? Fortunately, nowadays the rural countryside is of great importance to the culture of the British. The village has a high value; it is defined in the Cam- 


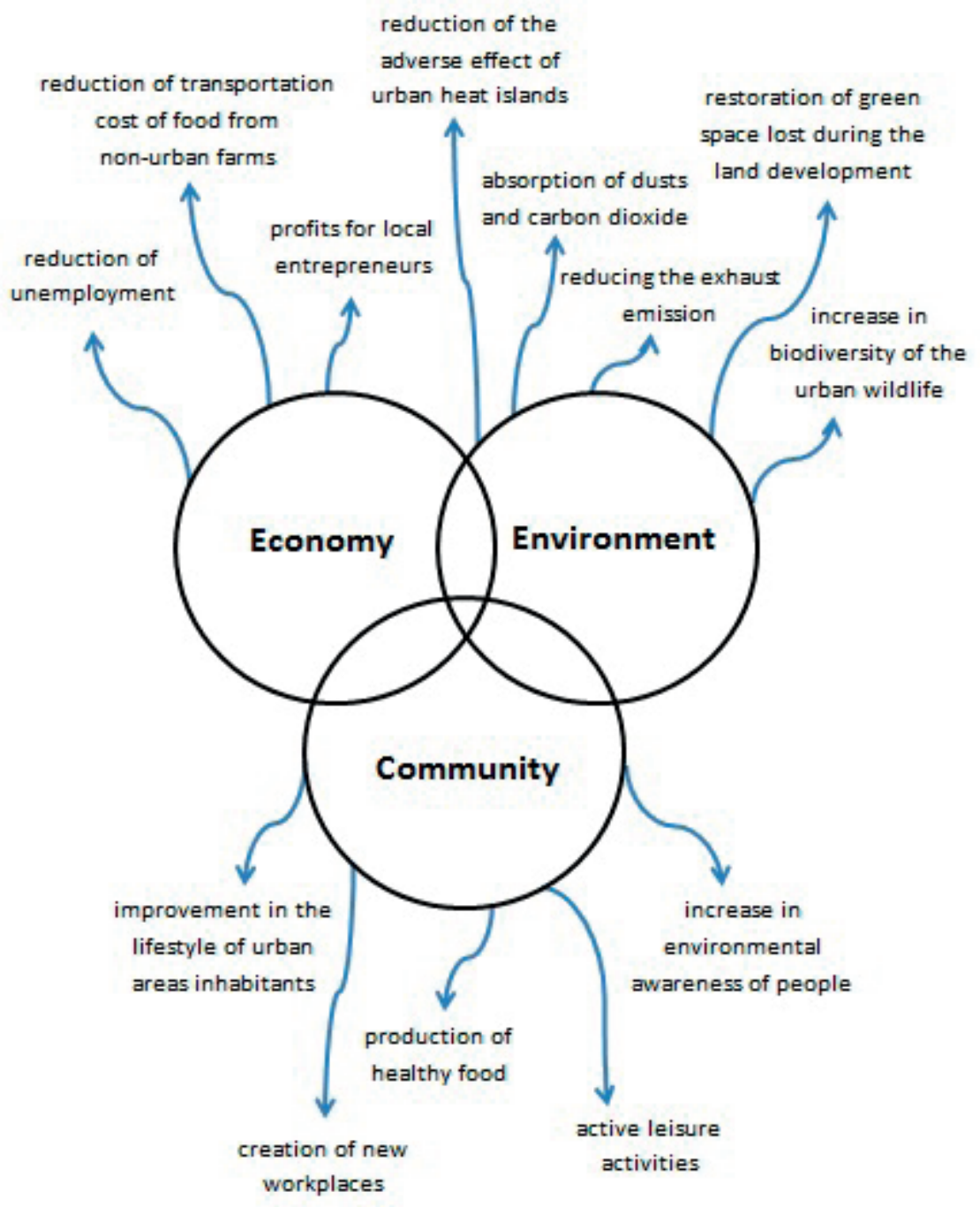

Figure 1. Profits generated by the creation of modern forms of urban agriculture in terms of sustainable development. (R. Jasionkowski based on W.M. Adams, IUCN, 2006)

bridge Dictionary as earth which is used for farming, and in its natural state can provide beautiful and magnificent scenery. It is here that there are places of special nature conservation values located in the middle of fields, while local populations care about biodiversity. This should be extended to city gardens as well, more easily leading to the production of food in addition to ornamental plants. Because people in the cities have their roots in the country, it is necessary to support and understand the importance of food production for people's lives and to maintain the normality in cities. This could be expressed in a publicly accessible farm located in a city, even in a global metropolis like London (Fig. 2).

A city farm may be considered by schools for their school activities, or as a place for voluntary and educational work, to learn how to produce food near home. This would not sever ties with the village, but would rather facilitate the dissemination of food production in a city among its inhabitants on a small scale for people's own use in home gardens as well as in their homes; it would also provide social benefits by allowing people to share experience with their neighbours and strengthen their neighbourly bonds.

\section{Obstacles and opportunities for city farming in Poland}

What is the current situation in Poland? Until recently, we produced a lot of food in home gardens. In recent years, Poland, as a rapidly developing country, has reported an 


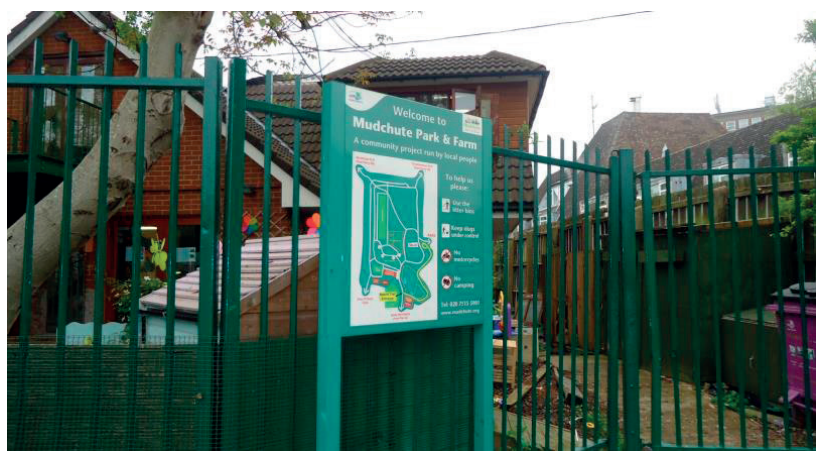

Figure 2. Entrance to the city farm in London (photo by A. Lewandowska-Czarnecka)

increase in the standard of living in cities. The availability of relatively cheap food has encouraged houses to display more ornamental plants, excluding space for food production. Agriculture in Poland has declined in this aspect. So what are the barriers and opportunities for the production of food in cities? First of all, in the era of universal education, the main focus is on the relationship with natural vegetation, occurring especially in national parks and nature reserves, while the interest in the agricultural landscape is much smaller. Similarly, garden plots have been converted into plots for recreation or for growing ornamental plants (Fig. 3). Perhaps it is time for a change, considering the same reasoning which is used in developed countries. Similarly, the production of food in cities makes it possible to use rural production for other crops, e.g. biomass. However agriculture in the cities undergo a risk of pollution involved in the urban environment. Current and past industrial activity, dense and dirty transport infrastructure, domestic burning of fossil fuels and the plethora of chemicals released into domestic waste streams all pollute the soil of cities (Meharg, 2016). In Poland, it has a special character because of the highly polluted air caused by car dependency and individual heat system in suburbs which is emphasized in the reports prepared by the European Environment Agency (2016).

\section{Conclusions}

The conditions of urban areas depend on the quality of the environment for the environment produces benefits called ecosystem services, inter alia: fresh air, potable water, healthy food and flood protection. Properly working ecosystems are crucial for the sustainable development of urban areas, because they have positive influence on human welfare and economic activity (Kronenberg, 2011). Revitalization of wastelands in urban areas and changing them into commonly accessible farms may represent an

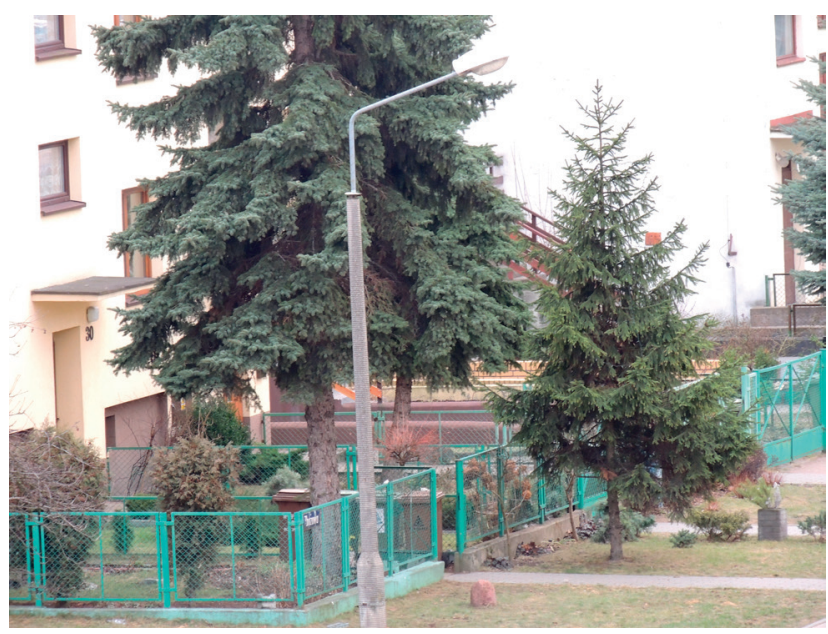

Figure 3. Ornamental plants in front gardens of detached houses in Toruń (photo by A. Lewandowska-Czarnecka)

effective way of using the ecosystem services and of improving the quality of life in a city.

Using the built-up areas and urban wastelands for such purposes will result in an increase in the biodiversity and retention of rainwater, as well as in the reduction of urban heat islands, improvement in the landscape aesthetics and - most importantly - the possibility of producing the ecological food in a city. If we allow for city farms in the plan of action for sustainable energy, we will have benefits not only in the reduction of carbon dioxide emission, but also we will be able to use the "wasted" areas in the ecological, aesthetical and functional way, as well as we will increase the biologically active surface and we will improve the microclimate of urban areas. It clearly appears from the balance of benefits coming from the establishment of city farms, green roofs, vertical vegetable gardens, small window or balcony plantations that, in accordance with the principle of sustainable development, such initiatives have positive impact on urban areas.

\section{References}

Adams W.M., 2006, The Future of Sustainability: Re-thinking Environment and Development in the Twenty-first Century, IUCN.

European Environment Agency, 2016, Air quality in Europe -2016 report.

Bailkey M. \& Nasr. J., 2001, From brownfields to greenfields: Producing food in North American cities, United Nations Development Programme, New York.

Bribach Ch., 2014, FLORAFELT Vertical Garden Guide, Norcross, Georgia. 
Denisowski A., 2001, Rolnictwo ekologiczne [Ecological agriculture], ODR, Koszalin.

Dobrzańska B.M., 2007, Planowanie strategiczne zrównoważonego rozwoju obszarów przyrodniczo cennych [Strategic planning for sustainable development of nature sites], Wydawnictwo Uniwersytetu w Białymsto$\mathrm{ku}$, Białystok.

Giecewicz J., 2005, Obszary rolne jako czynnik przyrodniczej rewitalizacji miast [Agricultural areas as a factor in natural revitalisation of cities], Teka Kom. Arch. Urb. Stud. Krajobr. - OL PAN, Warszawa.

Kania A., Mioduszewska M., Płonka P., Rabiński J.A., Skarżyński D., Walter E. \& Weber-Siwirska M., 2013, Zasady projektowania i wykonywania zielonych dachów i żyjących ścian. Poradnik dla gmin [Rules of design and construction of green roofs and vertical gardens], Stowarzyszenie Gmin Polska Sieć „Energie Cites", Kraków.

Kronenberg J., 2011, Ekonomia ekosystemów i bioróżnorodności w polityce lokalnej i regionalnej [The Economics of Ecosystems and Biodiversity in local and regional politics], Fundacja Sendzimira, Kraków.

Lewandowska-Czarnecka A., Nienartowicz A. \& Czarnecki A., 2015, Changes in Values of Emergy Sustainability Indices for Agricultural Holdings in Kujawy and Pomerania Regions after Accession of Poland to the European Union [in:] M.T. Brown, S. Sweeney, D. Campbell, S.-L. Huang, T. Rydberg, S. Ulgiati (eds), Emergy Synthesis 8, Proceedings of the $8^{\text {th }}$ Biennial Emergy Conference, The Center for Environmental Policy, University of Florida, Geinesville: 213-225.

Meharg A.A., 2016, Perspective: City farming needs monitoring. Nature 531: S60. [doi:10.1038/531S60a].
Palej A., 2010, Farmy miejskie - przedsięwzięcia wspomagające strategie zrównoważonego rozwoju miast. (Urban farms - enterprises supporting strategies of sustainable development of cities), [in:] S. Wehle-Strzelecka (ed.) Miasto oszczędne, T. 2 [Resource-efficient city, vol. 2], Czas. Tech., Arch./ PK, Kraków, 6-A/2: 39-44.

Poskrobko B., 2009, Sustainable development versus knowledge-based economy, Wydawnictwo Uniwersytetu w Białymstoku, Białystok.

Rabiński J.A., 2011, Dachy zielone - uwarunkowania formalnoprawne [Green roofs - formal and legal conditions], Polskie Stowarzyszenie Dachy Zielone, Wrocław.

Sznajda-Birnfeld E., Pływaczyk A. \& Skarżyński D., 2012, Zielone dachy. Zrównoważona gospodarka wodna na terenach zurbanizowanych [Green roofs. Sustainable water management in urban areas], Wydawnictwo Uniwersytetu Przyrodniczego we Wrocławiu, Wrocław.

Ustawa z dnia 27 kwietnia 2001 r. Prawo ochrony środowiska, Dz.U. 2001, Nr 62, poz 627, Warszawa [Law of 27 April 2001, Environmental Protection Law, Journal of Laws 2001, No 62, Item 627, Warsaw].

Walkow M., 2012, Przyroda w mieście. Usługi ekosystemów - niewykorzystany potencjał miast [Nature in the city. Ecosystem services - unused potential of cities], Fundacja Sendzimira, Warszawa.

Wilkin J., 2010, Bezpieczeństwo żywnościowe - koncepcje teoretyczne i instytucjonalne warunki realizacji [Food security - theoretical concepts and institutional conditions for implementation], Uniwersytet Warszawski, Warszawa. 